\section{Pouco além de um flagrante}

BORIS SCHNAIDERMAN

BORIS

SCHNAIDERMAN

é professor aposentado

da FFLCH-USP, tradutor

e ensaísta. É autor,

entre outros, de

Dostoiévski Prosa Poesia

(Perspectiva).
Boris Schnaiderman, "Apenas um Flagrante", in João Roberto Faria, Vilma Arêas, Flávio Aguiar (orgs.), Décio de Almeida Prado - Um Homem de Teatro, São Paulo, FapespEdusp, 1997

2 Cf. Vladímir Maiakóvski "Como Fazer Versos?", in Boris Schnaiderman, A Poética de Maiakóvski através de sua Pro sa, São Paulo, Perspectiva 1971 , p. 189.

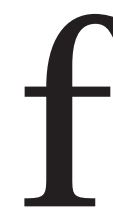

az tão pouco tempo que escrevi uma evocação-flagrante do meu convívio com Decio de Almeida Prado (1), e agora o inexorável me obriga a voltar a esse tema, desta vez com uma nota mais forte de admiração e saudade.

Sua figura não me sai da lembrança: alto, empertigado, os olhos claros que pareciam não se fixar no interlocutor, o que não era verdade, pois dificilmente haveria outra pessoa com a mesma capacidade de ouvir o próximo, de penetrar no que ele pudesse dizer. E o humor, marca permanente de sua fala, nunca se voltava contra quem estivesse com ele.

Quando o procurei, por intermédio de amigos, eu era o mais perfeito joão-ninguém, trabalhava na redação da Enciclopédia Mérito e já traduzira obras literárias do russo, todas assinadas com pseudônimo, e às quais nunca me referia. Anos antes, havia tentado o jornalismo-uma experiência decepcionante, que apenas reforçara um sentimento de frustração, em meio ao clima de desalento típico do cotidiano de tantos jovens durante o Estado Novo.
Colaborar no Estadão parecia algo completamente inconcebível, mas ali eu via diante de mim o diretor de seu Suplemento Literário. Como aconteceria mais de uma vez, eu o encontrei corrigindo provas, mas ele ergueu os olhos do papel e ouviu-me com toda a atenção.

Nenhum texto do Suplemento passava sem a sua revisão. O escrever bem e apresentar corretamente os textos sob sua responsabilidade ligava-se a uma postura ética, era uma questão de moral e de caráter (e imagine-se o que isso representava de trabalho, tanto mais que, na mesma época, fazia crítica de teatro no jornal).

Muitas vezes, ao receber-me, desculpava-se pela brevidade do encontro, e ia levar as provas à oficina. Descíamos então no mesmo elevador, e eu ouvia a barulheira dos linotipos.

A par de sua delicadeza, havia um critério muito pessoal na seleção dos textos. Nem sempre concordei com certas recusas de trabalhos meus, mas acabava compreendendo as suas razões, e a firmeza de ponto de vista fazia com que eu o admirasse mais ainda.

Este critério pessoal, porém, centravase apenas na qualidade do texto, nunca na tendência ou corrente que ele representava. Decio tinha certamente seu gosto bem definido, mas ele procurava sempre compreender aquilo que se afastava de suas próprias posições, e isso resultava numa grande abertura para o novo, o diferente.

E ao mesmo tempo, o jeito distinto, aristocrático, não propiciava aquele tipo de relação que Maiakóvski chegou a chamar de convívio ami cochon (amicochonstvo, um neologismo impagável em russo) (2). Ademais, havia de minha parte uma boa dose de timidez.

Mas ele sabia dizer uma palavra boa em relação a um texto, e eu devo muito ao seu estímulo discreto e eficaz.

Escrever no Estadão era algo muito complicado para mim. Sempre que ia levar ao Decio uma resenha ou artigo, pareciame que estava cometendo uma traição. $\mathrm{O}$ jornal tinha uma posição bem definida em relação aos dois blocos em confronto, e a minha era diametralmente oposta, não 
obstante as dúvidas que tinha em relação à realidade soviética. Dúvidas e, também, a convicção de que o caminho certo era exclusivamente aquele. Quando comparava as minhas dúvidas com o que via em volta acabava sufocando-as e impelindo-me cada vez mais para esquerda, embora não estivesse então filiado a nenhuma organização partidária (pudera! Minha capacidade de obedecer não resistira ao informe secreto de Khruschóv e aos acontecimentos na Hungria).

Ao mesmo tempo, eu via a receptividade com que Decio acolhia as posturas mais diversas (com exceção naturalmente das de extrema direita), e eu acabava lendo no Suplemento textos em que se sentia marca de esquerda. Num dos meus poucos encontros com Oto Maria Carpeaux, que também colaborava ali, cheguei a expor-lhe as minhas vacilações em relação ao nosso papel; ele deu uma pequena risada e insistiu comigo para que eu continuasse colaborando no jornal. O desenrolar da situação mostrou que o riso de Carpeaux era manifestação de sabedoria, pois Decio continuou muito aberto para o diálogo, certamente em meio a grandes dificuldades, e os colaboradores só eram tolhidos, a partir de 64, pela censura dos militares.
Todos nós que lidamos com textos literários não podemos deixar de lembrar-nos com o maior carinho dessa figura ímpar, que nos deu grande lição de convivência democrática e exigência intelectual.

Os anos em que participei do conselho editorial da Revista USP, por ele presidido (embora figurasse na página 2 entre os demais conselheiros, em ordem alfabética), apenas reforçaram em mim esta impressão. E eu nunca hei de esquecer aquelas reuniões, em que chegava pontualmente, sempre opinando sobre os trabalhos recebidos, com aquela distinção, aprumo e operosidade, mesmo quando já estava com a saúde muito debilitada. Conversar, trocar idéias, acrescentar uma nota de humor a tudo pareciam nele uma segunda natureza.

Algo absolutamente notável era a sua receptividade para os textos, mesmo se o autor não apresentava grandes "credenciais acadêmicas". E esta minha impressão fortaleceu-se ainda mais quando participei com ele de bancas de tese e dissertações de mestrado.

Agora que só é possível dialogar com Decio através da obra que nos deixou, ficam aqui estas poucas lembranças, ainda que desordenadas, de um convívio tão dignificante e enriquecedor.

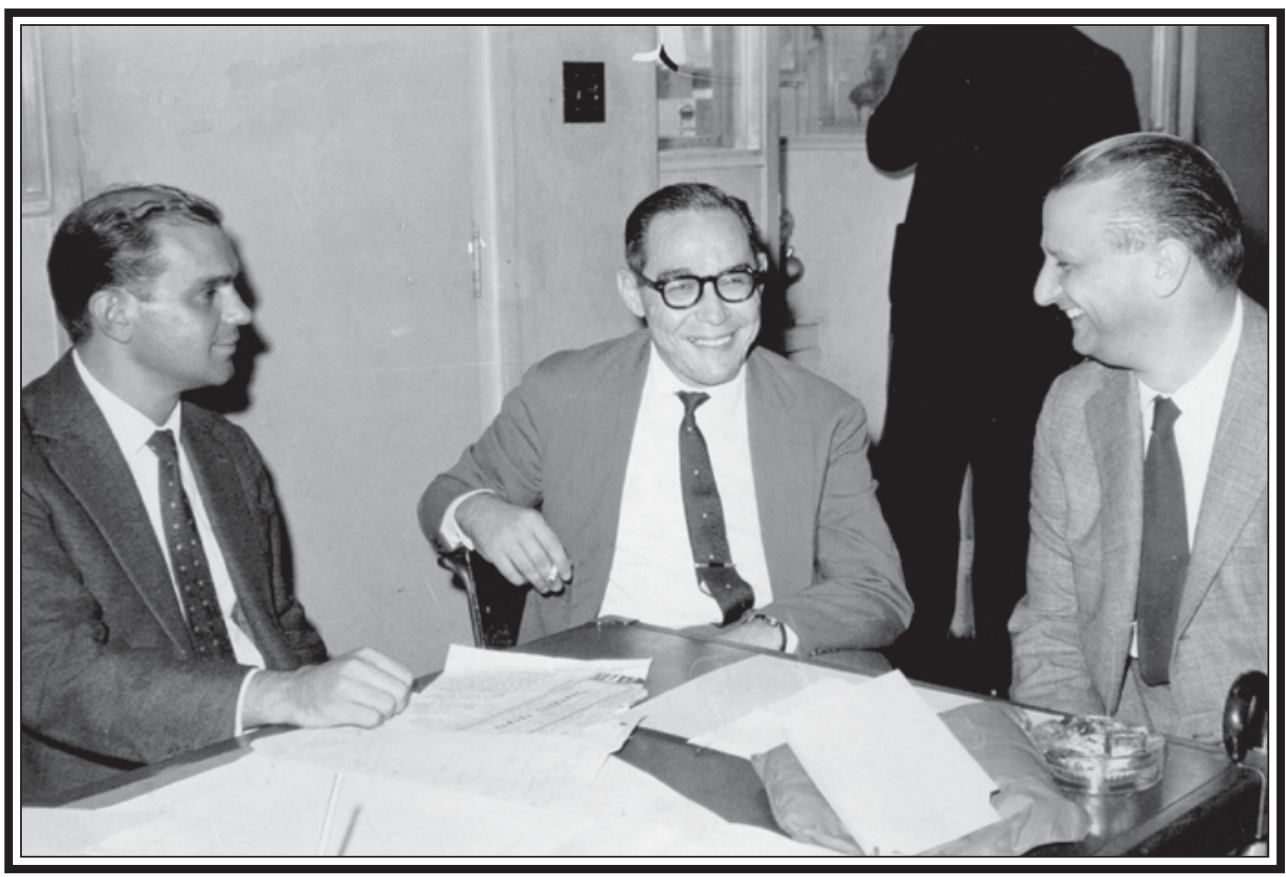

Sábato

Magaldi, Clóvis

Garcia e Decio 